\title{
Rule of Law Perceptions of Gulf Cooperative Council (GCC) Graduating Law Students
}

\author{
By Thomas Philip Corbin $\mathrm{Jr}^{*}$ \\ Richard Maguire ${ }^{* *}$
}

\begin{abstract}
Law students studying in Gulf Cooperative Council's (GCC) comparative law programs will provide excellent candidates for legal employment in the Middle East in the next couple of years as long as the students have high educational achievements, are functionally literate in both English and Arabic and have a firm belief in the Rule of Law. As many comparative law programs now exist in the GCC, programs conducting the instruction in English to students whose native language is Arabic and with high academic performance gauged by grades, the only true question comes down to the fundamental understanding of the Rule of Law and the optimistic belief that the Rule of Law will lead to changes in the employment of law students after graduation. To measure this knowledge and belief, a survey was given to a pool of law students at a GCC institution to gauge their understanding of the Rule of Law and their belief in the concept as a force of change in their own personal situations. The results and analysis are contained within this paper. Purpose Statement: The purpose of this project suggested by Dr. Thomas Corbin and supported by Dr. Richard Maguire is to gauge the personal belief in the Rule of Law as a concept of significance in the advancements of career goals in male and female law graduates. This project's initial review will act as a sounding board for future review of the belief of the Rule of Law in other groups of students.
\end{abstract}

\section{Introduction}

The New Need for Competent Adherents to the Rule of Law in the Gulf's Legal Market

In the coming years, the need for bi-lingual (English-Arabic) competent lawyers and law related professions will be the exception to the general notion that the legal career has reached a saturation point (Greenbaum 2010). The need for skilled attorneys with the language skills and the skills to understand comparative law issues today is a big concern to consider with a new batch of legal trainees that are being developed in the Kingdom of Saudi Arabia and

\footnotetext{
*Assistant Professor, Prince Mohammed Bin Fahd University, Saudi Arabia.

${ }^{* *}$ Assistant Professor, Prince Mohammed Bin Fahd University, Saudi Arabia.
} 
within the Gulf Cooperation Council (GCC). It is hypothesized that a group of high performing students engaged in comparative law and business law programs will be ideal candidates for employment if they are keenly aware of the rule of law as a concept, are willing to relocate within the Gulf for employment and can translate high performance in the classroom into the workplace.

The potential student who is engaged in the legal programs will be a great fit to work in the Gulf as they already speak the languages of trade, are personally concerned with the advancement of rule of law generally, and are concerned with fairness in the region. A survey conducted and reviewed has shown that, as a result of this interest, many of these qualifiers are existent in current students. As such, the concern exists as to their motivation to carry forward their academic success to the workforce while understanding the concept of the Rule of Law and being optimistic about it. Specifically, the very reason why they will be dynamic is because of the perception that they were incapable of working in the field up until recently because of cultural and Islamic religious values.

This perception that certain segments of the society were not able to compete or work in many fields of employment, including the law, is being challenged by motivated students at a couple of institutions in Saudi Arabia and GCC that believe that the motivated people, regardless of gender or other status, can be a staple contributor to the workforce and excel. This is commonly referenced by the Noble Quran 4:32 which says: Whatever men earn, they have a share of that and whatever women earn, they have a share in that.

Saudi Arabia itself has ratified various international agreements, protocols and laws. As such the need for the application of the rule of law in the instruction of students is paramount and the optimistic trust in the concept as a safeguarding agent is equally significant (Saudi Gazzette 2012). Programs are being designed to maximize the self-efficacy of students in this region. But are they optimizing the knowledge and belief in the concept of the rule of law? This query is a conrnerstone of the hypothesis and the research. Steps to highlight the belief in the rule of law and the continued optimistic forecast should be emphasized and monitored, with the goal of pushing the students to reach full potential and fill the employment gap need of the near future. As such, there is a need to gauge what current students understand about the rule of law, how optimistic they are about the future and they would be willing to relocate. The general purpose is to illustrate a small showcase of current students and how they would fit into the general hypothesis.

Particularly as Saudi Arabia grapples with the introduction of women into the legal profession, a growing pool of potential candidates to fill this skill set needed position are being educated in Saudi institutions. In May of 2013, an article in CNN introduced to its readership Arwa Al-Hujaili of Saudi Arabia and began to catalogue her attempts to be registered as the first female lawyer in Saudi Arabia. According to the rules of practice in Saudi Arabia, a lawyer may practice after a three year apprenticeship and this is the position that Ms. 
Al-Hujaili is currently in. The GCC legal world in general and women practitioners in particular stand in breathless anticipation and wait for Ms. AlHujaili's career to begin (Bozorgi 2013).

Additionally, educators in Saudi universities also look on and work to teach the current batch of law students, female and male alike, that there is hope and the educational process currently undertaken is not hollow. And it is in this endeavor that the current article looks at a very small batch group of students at a GCC learning institution's Comparative Law Program and business law classes in the business school that shows indication of great promise not only in the production of legal minds but in excellence in practice in years to come. Ideally, these students will be able to overcome more easily the workplace problems faced by Ms. Al-Hujaili and enter the workplace, not only in the Kingdom but also in neighboring GCC nations. This pool of students and employees to come, can be typified by their performance in relationship to their peers and also in relationship to their own personal struggles to complete their education and take their rightful place as practitioners of the legal profession or if not have high skills of employability in related markets. It is also understandable that the graduates in question will bring the zeal of practice from both professional and personal experiences upon graduation.

Teaching law in Saudi Arabia, as can be imagined, presents many interesting challenges. The law of Saudi Arabia is Sharia-based law (and for the purposes of this project the Constitution, arts. 46, 48, and 51-53 can be considered) that with a few notable exceptions, such as the basic law and labor law, has not been codified. Even when dealing with the written portions of the law, the interpretations of the law as it applies to the facts in a given case is left up to judicial interpretation, and the merits of stare decisis and uniformity of legal applications is left wanting. Compound this with a different perspective of fairness, justice and human rights from the student's perspective leads to the instructor needing to set down basic tenets of commonality to begin and expand upon (Hibbits, 2011 and Saudi Arabia, Royal Decree No. M/21 dated Ramadan 1389). However, it has become noteworthy that in the classroom demonstrations by a small cohort of students in relation to counterparts receiving the same reading material and the same assignments and graded by the same standards, that some gourps of students have demonstrated on the whole and in specific instances spectacular demonstrations of superior mastery of the topics presented. Such demonstration gives rise to a need to encourage quicker induction of graduating students of underrepresented groups into the legal and professional work force in the Kingdom of Saudi Arabia and in the GCC and also for legal recruiters, such as Gulf Talent to consider the graduating students for recruitment and placement into positions in neighboring GCC states.

From a professional standpoint, emphasis on rule of law, which calls for a more egalitarian view, such as in the Magna Carta of 1215, in application of the law to all people, is a hallmark of all educational curriculums. Using the 
ABA's World Justice Project as a template of a "broadly" defined rule of law which calls for rule of law to be an essential building block for societies to "offer opportunity and equity to all their citizens" and in this instance facilitate the employment of high performing female graduates from law programs in the GCC to the job market in the nations' region.

To give some background, in 2007 ABA President William Neukom established the World Justice Project. The World Justice Project recognizes the problem that "the 'rule of law' is a frequently used term that is rarely defined." One goal of the World Justice Project is to develop a broadly accepted definition of the rule of law that could be used to measure adherence to the rule of law both in the United States and abroad. Based on the belief that the rule of law is a prerequisite for building societies that offer opportunity and equity to all their citizens, the World Justice Project proposes to use its definition of the rule of law to create an index that will measure how nations around the world are - or are not—-following the rule of law.

\section{Analysis of Survey Results on Rule of Law and Potential Employment}

To affirm the statements made above, a group of grades earned over the last couple of semesters could be compared amoung students. But grades may not be enough. The perception of GCC male students as the one group, and in particular Sharia law as applied in the Kingdom of Saudi Arabia, may present considerable challenges to under-represented groups that wish to work. Furthermore, the faith and courage to believe that the equal application of the law in all matters will be ensured must be supported at the educational level to then be ported into the employment sector. This was summed up best in United States v. United Mine Workers, 330 U.S. 258 (1947) in which the U.S. Supreme Court said: "There can be no free society without law administered through an independent judiciary. If one man can be allowed to determine for himself what is law, every man can. That means first chaos, then tyranny." Islam's Women Jewel of Islam website, however, points out Saudi Arabia's strict interpretation of the Islamic laws subjugates women to men in "all" matters. To get a sampling of what high performing female students' expectations may be, a survey was conducted on their perceptions of optimism and opportunity.

\section{Methodology}

The intent of this current mixed quantitative and qualitative, descriptive study is to identify the perceptions of GCC law students regarding their perceptions of success in the field of law. To understand better the relationships between the various variables, ordinal and nominal data of GCC students' perceptions were sought to measure the participants' levels of perceptions of success in relation to the perception and self-efficacy of the rule 
of law.

\section{Hypotheses}

The use of null hypotheses indicates that no differences exist between variables in the study (Creswell, $2005 \&$ Neuman, 2003). The lack of support for a null hypotheses leads to the probability that the alternate hypotheses is true and that differences between variables in the study are evident (Creswell, $2005 \&$ Neuman, 2003). In this study each set of independent and dependent variables became the basis for the null ( $\mathrm{H} 0)$ and alternative (HA) hypotheses. Females were compared to male participants as to their perceptions of optimism and opportunity as a measure of their self-efficacy.

Oswell (2005) used an empirical phenomenological modified van Kaam method. Moustakas (1994) defined this method by stating that "the empirical phenomenological approach involves a return to experience in order to obtain comprehensive descriptions that provide the basis for a reflective structural analysis that portrays the essences of the experience" (p. 13). Moustakas asserted that "perception is regarded as the primary source of knowledge, the source that cannot be doubted" (p. 44). Moustakas' modified van Kaam Method focuses on attitudinal perception can be used to help understand perceptions. The survey instrument served as the tool for identifying the level of perceptions regarding the self-efficacy of students' employment opportunities as connected to the concept of the Rule of Law.

\section{Hypothesis One}

H10: Business students studying law concepts and law students perception of the Rule of Law does not significantly affect their self-efficacy.

H1A: Business students studying law concepts and law students' perception of the Rule of Law does significantly affect their selfefficacy.

\section{Results and Findings}

The survey garnered the participation of the sample group of 60 students (30 male and 30 female). Through descriptive analysis the questions were quantified and qualified and the results of the finding are charted in Appendix 2. The concept of the rule of law was explored as to questions 4 and 5 and the results demonstrated that the students had a marginal awareness of the rule law and after reviewing the material had an increase of awareness of the concept by a margin of twenty six percent. Qualitatively, question 6 as demonstrated on a Likert scale, demonstrated a rightward skew for optimism while question 7 demonstrated a simliar response partern on impact of rule law on employment 
opportunities. But perhaps most interestingly, question 8 , which dealt with relocation to a different country with a higher rule of law index score for employment demonstrated that females were twice as likely, or specifically fourty eight percent more likely to relocate for employment. Lastly, question 9, which dealt with optimistic views of rule of law in employment opportunities, showed high optimism as the data statstically favored high optimism for both males and females.

\section{Conclusion and Comments}

In conclusion, the research data demonstrated from the survey instrument a strong preponderance of evidence supporting the alternative hypothesis which stated that business students studying law concepts and law students ${ }^{6}$ perception of the Rule of Law does significantly affect their self-efficacy.

From a law school education standpoint, more emphasis on the rule of law needs to be intergrated into the curriculum, and encouragement for graduates to explore all options for legal and professional employment, including relocation, should be a top consideration. An assessment should be designed to measure outcomes of graduates to track their career tracks based on employment in high index rule of law nations versus low index nations, compared to where their original point of graduation took place through their student affairs alumni association. It should also be a concern, for brain drain or intellectual flight reasons, that low index rule of law nation will continue to lose their best and brightest as they will feel uninhibited to follow economic and self-efficacy determinations. What may be of even greater significance for social consideration is the willingness of female graduates to seize their educational and career paths in locales that will allow for a more fluid advancement within the career.

\section{Work Cited}

Bozorgi, S. (2013). "Women Criminal Defense Attorneys: First Women Lawyer Registered in Saudi Arabia", Women Criminal Defense Attorneys, A Blog for Champions of Justice Who Just Happen to be Women. Available at http://www. womencriminaldefenseattorneys.com/women-criminal-defense-attorneys-firstwoman-lawyer-registered-in-saudi-arabia/ [17 April 2013].

Carrington, D. “Meet Saudi Arabia's First Female Lawyer." www.cnn.com. May 9, 2013. [13 October 2013].

Creswell, J. W. (2002). Educational research: Planning, conducting evaluating quantitative and qualitative research. Upper Saddle River, NJ: Pearson Education, Inc. as cited in Maguire, R. K. (2010). Perceptions of the effectiveness of school drug policy programs and potential implementation of drug testing. (Order No. 3510724, University of Phoenix). ProQuest Dissertations and Theses, 159. Available at http://search.proquest.com/docview/1015386037? accountid $=35812$. (1015386037). [18 November 2013]. 
"Department of Law." Home page. Dept. of Law, Prince Mohammed Bin Fahd U, 2013. Available at http://www.pmu.edu.sa/Academics/Law_Dept_CAS_UDP. aspx. [16 April 2013].

Greenbaum, M. (2010). "Too Many Lawyers? Too Many Law Schools." Stephen Bainbridge's Journal of Law, Politics, and Culture. Available at http://www.pro fessorbainbridge.com/professorbainbridgecom/2010/01/too-many-lawyers-toomany-law-schools.html [25 August 2013].

Gulf Talent. www.gulftalent.com. [13 April 2013].

Hibbits, Bernard J. (2010). "Courts \& Judgments, Saudi Arabia-Judiciary.” The Jurist: The Legal Education Network. Available at http://jurist.law.pitt.edu/world/saudia rabia.htm. [19 April 2013].

Magna Carta, 1215.

Moustakas, C.E. (1994). Phenomenological research methods. Thousand Oaks, CA: Sage. As cited in Maguire, R. K. (2010). Perceptions of the effectiveness of school drug policy programs and potential implementation of drug testing. (Order No. 3510724, University of Phoenix). ProQuest Dissertations and Theses, 159. Available at http://search.proquest.com/docview/1015386037?accountid=35812. (1015386037). [18 November 2013]

Neuman, L. W. (2003). Social research methods: Qualitative and quantitative approaches. (5th ed). Allyn and Bacon. As cited in Maguire, R. K. (2010). Perceptions of the effectiveness of school drug policy programs and potential implementation of drug testing. (Order No. 3510724, University of Phoenix). ProQuest Dissertations and Theses, 159. Available at http://search.proquest.com/ docview/1015386037?accountid=35812. (1015386037). [18 November 2013].

Oswell, M. L. (2005). A phenomenological inquiry: Managers' perceptions on AfricanAmerican male's capacity to lead. D.M. University of Phoenix. As cited in Maguire, R. K. (2010). Perceptions of the effectiveness of school drug policy programs and potential implementation of drug testing. (Order No. 3510724, University of Phoenix). ProQuest Dissertations and Theses, 159. Available at http://search.proquest. com/docview/1015386037?accountid=35812. (1015386037). [18 November 2013].

Noble Quran. Print.

Saudi Arabia, Royal Decree No. M/21 dated Ramadan 1389

Saudi Arabia, Const. Arts. 46, 48, and 51-53. Print.

Shobokshi, H. (2012). "Establishing the Rule of Law." Editorial, Saudi Gazette. Available at http://www.saudigazette.com.sa/index.cfm?method=home.Regcon \& contentID=20120423122510. [15 April 2013].

"Women in Islam.” Islam's Women Jewels of Islam Online. Islam's Women, 2013. Available at http://www.islamswomen.com/index.php. [10 November. 2013].

"World Justice Project." ABA Online. American Bar Association, 2007. Available at http://www.americanbar.org/content/dam/aba/migrated/publiced/features/Part1Di alogueROL.authcheckdam.pdf. [9 November. 2013].

"World-2013" Map. Rule of Law Index Map, 2013. World Justice Project, 2013. Available at http://worldjusticeproject.org/. [17 November. 2013].

United States v. United Mine Workers, 330 U.S. 2581947.

United States. Depart. of State. A Service of Consular Affairs: Travel-Country Specific Information, Saudi Arabia. 2013.

Van Kaam, A. L. (1984). Existential foundations of psychology. Lanham, MD: University Press of America. As cited in Maguire, R. K. (2010). Perceptions of the effectiveness of school drug policy programs and potential implementation of drug testing. (Order No. 3510724, University of Phoenix). ProQuest Dissertations 
and Theses, 159. Available at http://search.proquest.com/docview/1015386037 ?accountid=35812. (1015386037). [17 November 2013]

\section{Appendix 1}

\section{Rule of Law Survey}

\section{Instructions}

Please read the following passage and review the provided website.

After you have reviewed the passage and website, please answer the questions that follow.

\section{The Rule of Law and the ABA World Justice Project}

In 2007, ABA President William Neukom established the World Justice Project. The World Justice Project recognizes the problem that "the 'rule of law' is a frequently used term that is rarely defined." One goal of the World Justice Project is to develop a broadly accepted definition of the rule of law that could be used to measure adherence to the rule of law both in the United States and abroad. Based on the belief that the rule of law is a prerequisite for building societies that offer opportunity and equity to all their citizens, the World Justice Project proposes to use its definition of the rule of law to create an index that will measure how nations around the world are-or are notfollowing the rule of law.

The World Justice Project has proposed a working definition of the rule of law that comprises four principles:

1. A system of self-government in which all persons, including the government, are accountable under the law

2. A system based on fair, publicized, broadly understood and stable laws

3. A fair, robust, and accessible legal process in which rights and responsibilities based in law are evenly enforced

4. Diverse, competent, and independent lawyers and judges

Please review the following website: http://worldjusticeproject.org/rulelaw-index-map

\section{Research Questions:}

1. What is your gender?
a. Male
b. Female

2. What is your age?

3. What year of college are you ranked? (circle one)

a. Freshman b. Sophmore

c. Junior d. Senior e. Graduate

4. Prior to this information provided to you, where you aware of the concept of the Rule of Law?
a. Yes
b. No 
5. After reviewing this information has your perception of the concept of the Rule of Law changed?
a. Yes
b. No
Please briefly explain:

6. Are you optimistic about your employment chances after graduation?

a. Yes b. No

b. Rate your response where 1 is not optimist and 10 is most optimistic (circle one)

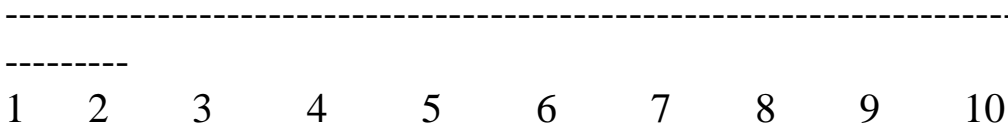

Please briefly explain:

7. Do you believe that the Rule of Law has an impact on your employment opportunities?

a. Yes

b. No

c. Rate your response where lindicates that Rule of Law has no impact on employment opportunities and 10 indicates Rule of Law is fundamental to employment opportunities. (circle one)

$\begin{array}{llllllllll}1 & 2 & 3 & 4 & 5 & 6 & 7 & 8 & 9 & 10\end{array}$

Please briefly explain:

8. Would you consider relocating to another country with a higher Rule of Law Index score for employment?
a. Yes
b. No

9. Would you say that you are optimistic about Rule of Law being a productive force in your future employment opportunities?
a. Yes

b. No 
Vol. 1, No. 2 Corbin et al: Rule of Law Perceptions of Gulf Cooperative Council...

c. Rate your response where 1 is not optimist and 10 is most optimistic (circle one)

$\begin{array}{llllllllll}1 & 2 & 3 & 4 & 5 & 6 & 7 & 8 & 9 & 10\end{array}$

10. Do you have any other input or opinions that you would like the survey operators to know about?

Please briefly explain:

\section{Appendix 2}

Rule of Law Survey Results

November 2013

Q1

Sample size

Male Female

$30 \quad 30$
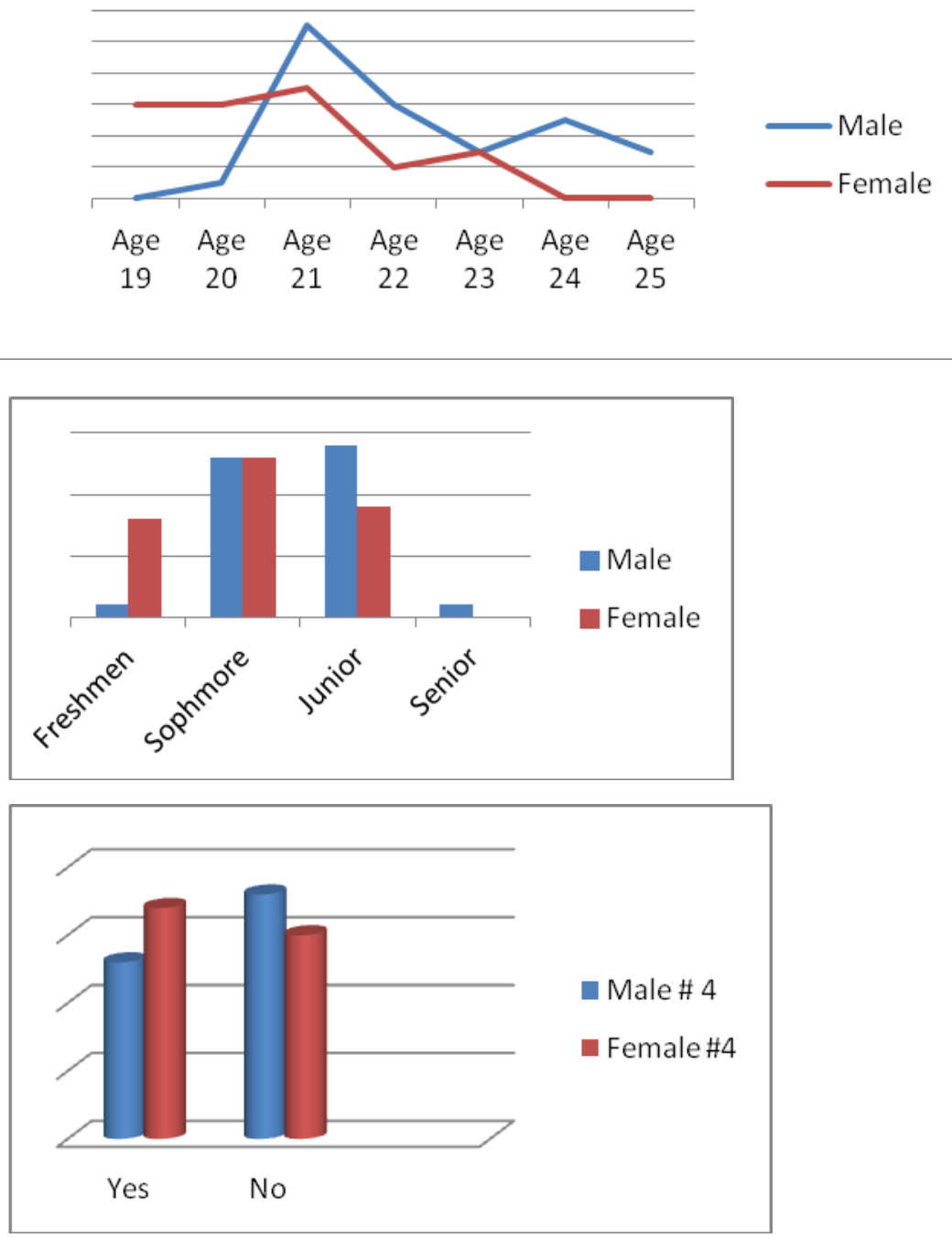

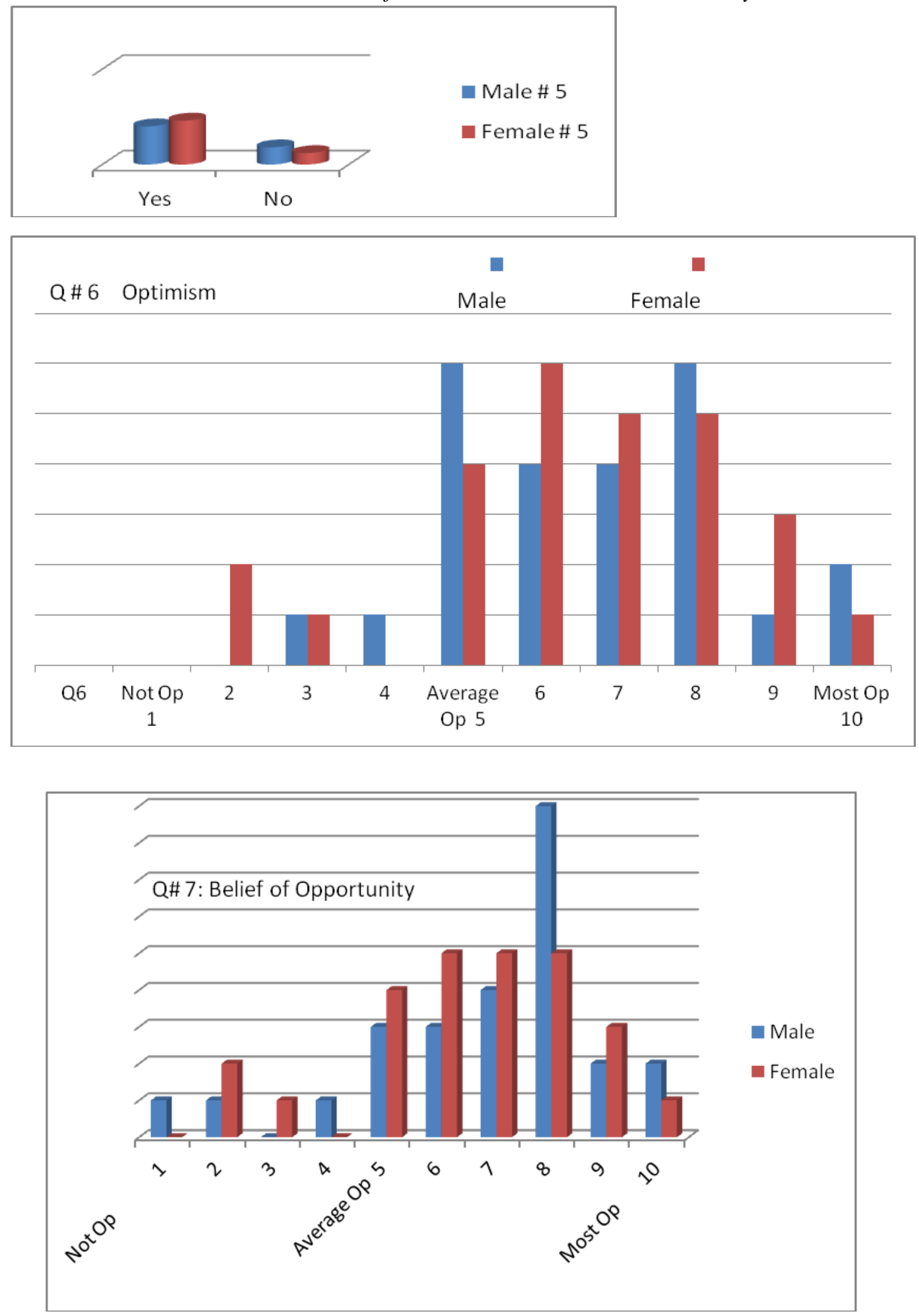
Vol. 1, No. 2 Corbin et al: Rule of Law Perceptions of Gulf Cooperative Council...

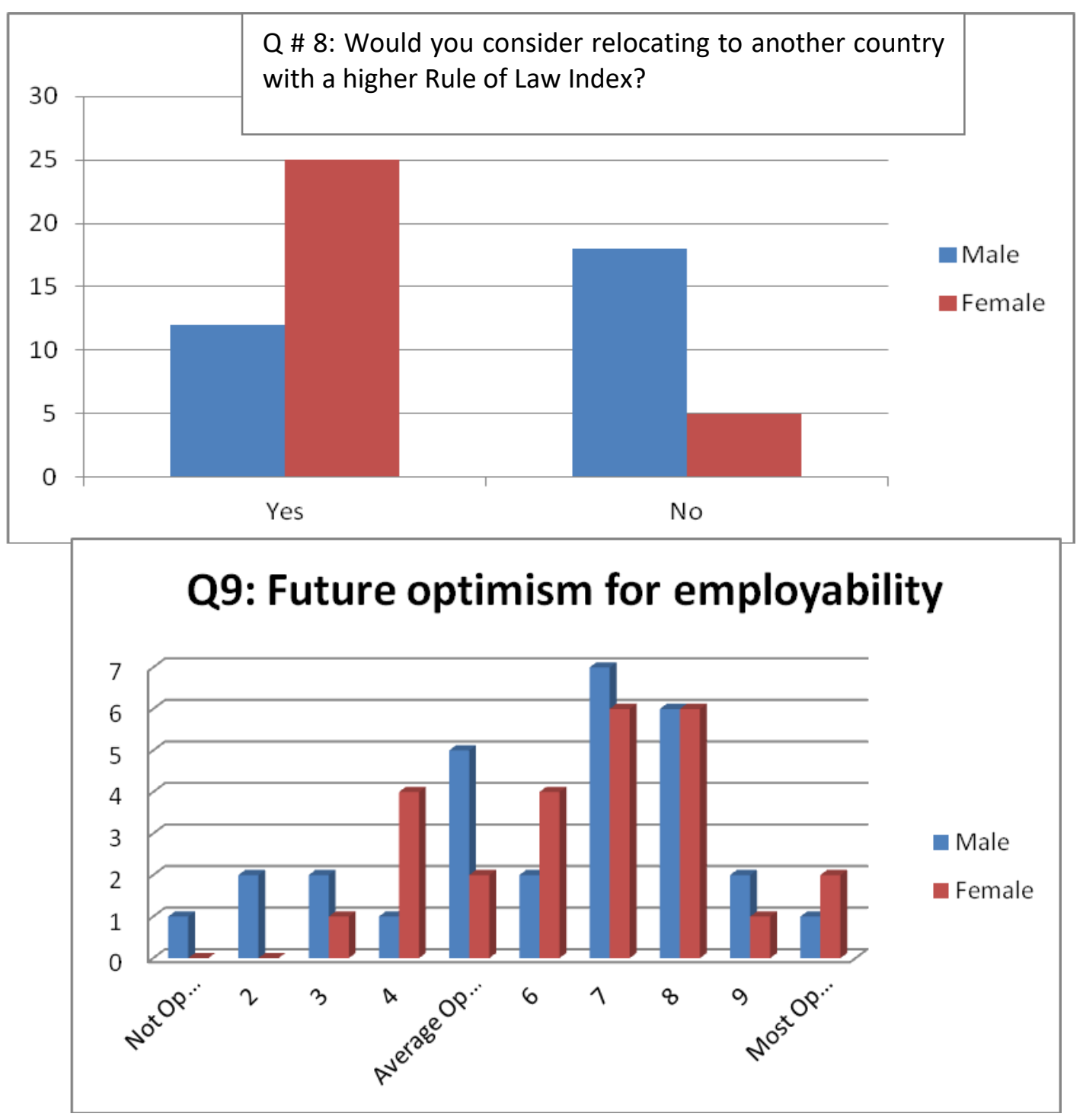

